16

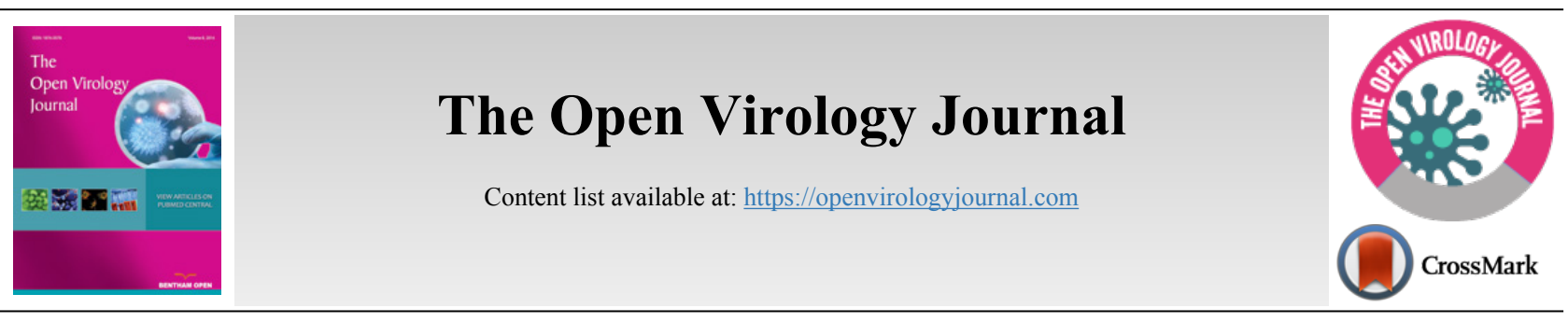

PERSPECTIVE ARTICLE

\title{
Strategies and Challenges to Develop Therapeutic Candidates against COVID-19 Pandemic
}

\author{
Rohit Bhatia ${ }^{1, *}$, Subrahmanya S Ganti ${ }^{1}$, Raj Kumar Narang ${ }^{2}$ and Ravindra Kumar Rawal ${ }^{3}$ \\ ${ }^{1}$ Department of Pharmaceutical Chemistry, ISF College of Pharmacy, Moga, Punjab-142001, India \\ ${ }^{2}$ Department of Pharmaceutics, ISF College of Pharmacy, Ferozepur G.T. Road, Moga-142 001, Punjab, India \\ ${ }^{3}$ Department of Chemistry, Maharishi Markandeshwar (Deemed to be University), Mullana-133207, Haryana, India
}

Keywords: Pandemic , COVID-19, Therapeutic candidates, Epidemics, Respiratory syndrome, SARS-CoV .

\begin{tabular}{|l|l|l|c|}
\hline Article History & Received: May 07, 2020 & Revised: July 07, 2020 & Accepted: August 08, 2020 \\
\hline
\end{tabular}

\section{PERSPECTIVE}

The terrible story of the coronavirus disease (COVID-19) needs no introduction in the present hour. It is evident that viral diseases have always appeared as a mystery and are the fatal ailments in human beings. The history justifies this fact of viral epidemics, such as SARS-CoV prevailed during 2002-2003, H1N1 during 2009, MERS-CoV in 2012 and the most dreadful COVID-19 from December 2019 to till date [1]. This ailment has emerged as a wonderstruck and put the whole world in worry and confusion. According to the latest WHO situation report-90, up to $29^{\text {th }}$ April, there are 30,18,681 total confirmed cases of COVID-19 and approximately 2,07,973 people had lost their lives all over the world [2]. Coronaviruses (CoVs) are the major microorganisms causing fatal respiratory disease outbreaks worldwide. These constitute a large group of singlestranded RNA viruses and can be isolated from a wide variety of animal species $[3,4]$. CoVs have an appearance like a crown (coronam a Latin term) due to the presence of glycoprotein spikes on its envelope [5]. To date, seven human coronaviruses (HCoVs) have been identified. The common $\mathrm{HCoVs}$ are $\mathrm{HCoV}-\mathrm{OC} 43$, and HCoV-HKU1; HCoV-229E and HCoVNL63 $(\alpha \mathrm{CoVs})$, which are responsible for the common cold and lower extent of upper respiratory disorders. Other HCoVs are severe acute respiratory syndrome causing coronavirus (SARS-CoV), SARS-CoV-2 and the Middle East respiratory syndrome causing the coronavirus (MERS-CoV), which can cause epidemics with severe respiratory manifestations [6].

\section{PATHOGENESIS OF COVID-19}

The progression of COVID-19 can be divided into three

\footnotetext{
* Address correspondence to this author at the Department of Pharmaceutical Chemistry, ISF College of Pharmacy, Moga, Punjab-142001, India; Tel: 8628885561; E-mail: bhatiarohit5678@gmail.com
}

major stages: Asymptomatic stage, upper airway response stage and progression to Acute Respiratory Distress Syndrome (ARDS) [7]. The first stage is regarded as the stage after 1-2 days of the infection. In this, SARS-CoV-2 enters the nasal cavity and gets bounded to epithelial cells there with the help of the ACE2 receptor [8,9]. When it enters inside the cell, the viral RNA gets released into the cytoplasm of the cell where translation occurs, leading to the formation of proteins and replication [10]. It starts replicating and ciliated cells are believed to be infected here [11]. It is the local propagating stage, viral loads are low, and the infection can be detected by using nasal swabs. The innate immune response at this stage is low. In the next few days, the virus starts propagating towards lower respiratory track along with conducting organs and the extent of innate immune response gets elevated. At this stage, the sputum analysis represents a virus and other markers of innate immunity. It confirms the manifestation of COVID-19 disease. The level of cytokine CXCL10 can be predicted for clinical studies [12]. The infected epithelial cells yield beta and lambda interferons [13]. CXCL10 is a gene that is highly responsive to interferons in alveolar type II cell response in the case of SARS-CoV and is also a disease marker for SARS [14 16]. It was evident that for about $80 \%$ of infected people, the disease was mild and limited only to the upper respiratory region. The rest of about $20 \%$ sufferers, unfortunately, go to severe stage 3 and are associated with respiratory infiltrates. The virus enters the lungs and alveolar type II cells and liesin peripheral or pleural sites [17]. A large population of viruses gets released and cells undergo apoptosis and ultimately die. The results are the development of pulmonary toxin, which invades the adjacent cells leading to secondary pathway initiation foe regeneration of epithelial cells [18]. It is reported that these manifestations led to alveolar damage with the evident presence of fibrin rich membranes and giant cells [19]. 
To recover at this stage, a vigorous immune response is required with extremely rapid epithelial regeneration. The elder people are at very much higher risk at this stage due to low immune response and slow epithelial regeneration. This pathogenesis is not still $100 \%$ clear and may take few more months to resolve the unclear mechanisms.

A huge number of research groups from all parts of the world are continuously working in order to develop therapeutic agents against COVID-19, but no vaccine or therapeutic candidate has been developed to date. The rapidly expanding knowledge regarding SARS-CoV-2 virology provides a significant number of potential drug targets. These targets include spike protein (S), an envelope protein (E), membrane protein (M), protease, nucleocapsid protein, hemagglutinin esterase, helicase and several Nonstructural Proteins (NSPs) [20 - 22] which are currently being focussed for drug discovery and drug development. The drugs or vaccines which are currently under investigation or in clinical trials against COVID-19 have been depicted in (Table 1).

Table 1. Drugs under investigation against COVID-19.

\begin{tabular}{|c|c|c|c|c|}
\hline $\begin{array}{l}\text { Therapeutic } \\
\text { Class }\end{array}$ & $\begin{array}{c}\text { Therapeutic } \\
\text { Agent }\end{array}$ & Description & Current Status & Reference \\
\hline $\begin{array}{l}\text { Interleukin } \\
\text { Antagonist }\end{array}$ & Anakinra & $\begin{array}{l}\text { Interleukin-I (IL-I) receptor } \\
\text { antagonist with an intent to end } \\
\text { cytokine invasion }\end{array}$ & Under clinical trial (NCT04330638) & {$[23]$} \\
\hline Antibody & Baricitinib & $\begin{array}{c}\text { Janus Kinase (JAK) inhibitor, } \\
\text { recommended through an artificial } \\
\text { intelligence approach }\end{array}$ & Clinical data not available & {$[24]$} \\
\hline Antibody & Bevacizumab & $\begin{array}{l}\text { A recombinant humanized antibody } \\
\text { which prevents the association of } \\
\text { vascular endothelial growth factor } \\
\text { with its receptors which is official } \\
\text { in the USA against multiple cancers }\end{array}$ & $\begin{array}{l}\text { Under evaluation in a clinical trial in China against } \\
\text { COVID-19 (NCT04275414) }\end{array}$ & {$[25]$} \\
\hline Antibiotic & Brilacidin & $\begin{array}{c}\text { A defensive peptidomimetic under } \\
\text { development by Innovation } \\
\text { Pharmaceuticals }\end{array}$ & Under evaluation against SARS-CoV-2 & {$[26]$} \\
\hline Anti-Malarial & Chloroquine & \begin{tabular}{|c|} 
Elevates endosomal $\mathrm{pH}$ and \\
interferes with ACE2 glycosylation
\end{tabular} & $\begin{array}{l}\text { Under evaluation in a clinical trial (NCT04344951) against } \\
\text { COVID-19 }\end{array}$ & {$[27]$} \\
\hline Antiviral & Darunavir & HIV-protease inhibitor & $\begin{array}{l}\text { Under evaluation in a clinical trial (NCT04252274), still, no } \\
\text { clinical human data is reported in support of its use against } \\
\text { COVID-19 }\end{array}$ & {$[28]$} \\
\hline Antibody & Eculizumab & $\begin{array}{l}\text { Humanized monoclonal IgG } \\
\text { antibody, responsible for the } \\
\text { prevention of formation of } \\
\text { membrane attack complex by } \\
\text { binding to complement protein C5 }\end{array}$ & $\begin{array}{l}\text { Under evaluation in a clinical trial (NCT04288713) for } \\
\text { COVID-19 }\end{array}$ & {$[29]$} \\
\hline Antiviral & Favipiravir & $\begin{array}{c}\text { RNA dependent RNA polymerase } \\
\text { (RdRp) inhibitor with wide anti- } \\
\text { viral activity }\end{array}$ & $\begin{array}{l}\text { Under evaluation in a clinical trial (NCT04273763) against } \\
\text { COVID-19 }\end{array}$ & {$[30]$} \\
\hline Antiviral & Galidesivir & $\begin{array}{l}\text { Nucleoside RNA polymerase } \\
\text { inhibitor against Ebola virus }\end{array}$ & Currently under evaluation by Biocryst Pharma & [31] \\
\hline Antiviral & Griffithsin & $\begin{array}{c}\text { An algae derivative as a potent HIV } \\
\text { entry inhibitor }\end{array}$ & $\begin{array}{l}\text { Reported active against SARS-CoV-1 and under evaluation } \\
\text { against SARS-CoV-2 }\end{array}$ & {$[32]$} \\
\hline Antiviral & Lopinavir & $\begin{array}{l}\text { Viral proteases inhibitor (3CLpro } \\
\text { or PLpro) }\end{array}$ & $\begin{array}{l}\text { The repurposed drug, currently under clinical trials } \\
\text { (NCT04307693) }\end{array}$ & {$[33]$} \\
\hline Antiviral & Nelfinavir & HIV-1 protease inhibitor & $\begin{array}{l}\text { Homology modelling in silico activity is reported but no } \\
\text { clinical data available }\end{array}$ & {$[34]$} \\
\hline Antihelmintic & Niclosamide & Kills tapeworms & $\begin{array}{c}\text { Have in vitro activity against SARS-CoV-1, under } \\
\text { investigation against SARS-CoV-2 }\end{array}$ & {$[35]$} \\
\hline Antiviral & Remdesivir & $\begin{array}{l}\text { RdRp inhibitor and blocks viral } \\
\text { replication }\end{array}$ & $\begin{array}{c}\text { Under evaluation against SARS-CoV-2 in clinical } \\
\text { trials(NCT04302766,NCT04292899, NCT04292730, } \\
\text { NCT04280705) }\end{array}$ & {$[36-38]$} \\
\hline Antiviral & Sofosbuvir & Antiviral against Hepatitis $\mathrm{C}$ & $\begin{array}{l}\text { Reported in vitro activity against SARS-CoV-1, under } \\
\text { investigation against SARS-CoV-2 }\end{array}$ & [39] \\
\hline Anti-oxidant & Vitamin C & Anti-oxidant & $\begin{array}{l}\text { A clinical trial is going on in China for COVID-19 } \\
\text { (NCT04264533) }\end{array}$ & {$[40]$} \\
\hline Antiviral & Umifenovir & Antiviral against Influenza & $\begin{array}{l}\text { Evaluated in Chinese clinical trials (200mg orally thrice a day } \\
\text { for no more than } 10 \text { days) for COVID-19 revealed potent in } \\
\text { vitro activity }\end{array}$ & [41] \\
\hline
\end{tabular}


(Table 1) contd.....

\begin{tabular}{|c|c|c|c|c|}
\hline $\begin{array}{l}\text { Therapeutic } \\
\text { Class }\end{array}$ & $\begin{array}{l}\text { Therapeutic } \\
\text { Agent }\end{array}$ & Description & Current Status & Reference \\
\hline Herb & XueBijing & Chinese herbal extract & $\begin{array}{l}\text { Administration of this extract has remarkably reduced the } \\
\text { mortality rate due to COVID-19 in China, administered as } \\
100 \mathrm{ml} \text { intra venous infusion twice a day }\end{array}$ & {$[42]$} \\
\hline $\begin{array}{l}\text { Interleukin } \\
\text { Antagonist }\end{array}$ & Tocilizumab & $\begin{array}{c}\text { Interleukin-6 (IL-6) receptor } \\
\text { inhibitor humanized monoclonal } \\
\text { antibody which can restore T Cell } \\
\text { counts }\end{array}$ & $\begin{array}{l}\text { Under evaluation in a clinical trial (NCT04317092) against } \\
\text { COVID-19 }\end{array}$ & {$[43,44]$} \\
\hline
\end{tabular}

Various treatment strategies to treat and manage the SARS-CoV-2 infection have been summarized in the following sections.

\section{DEVELOPMENT OF ANTIBODIES TO SARS-COV-2}

It is well known that the entry of coronavirus is mediated by $\mathrm{S}$ protein followed by the release of viral nucleocapsid inside the cell for the purpose of replication [45]. S protein also causes symplasm formation between normal receptor-bearing cells and infected cells around them. Targeting the surface of SARS-CoV-2 with a neutralizing antibody has been looked for thoroughly by various research groups in order to provide a passive immunity [46]. The gene synthesis can be carried out in a laboratory considering the expression of $\mathrm{S}$ protein as an immunogen utilizing the recently launched genome sequence of SARS-CoV-2 (GenBank: MN908947.3). Traditional methods using experimental animals are also available but they are too slow as per the current situation of this pandemic. Instead, faster methods such as the utilization of phage library or yeast display library to express specific antibodies can be utilized for viral neutralization $[47,48]$. The challenges in this task are rigorous testing in cell culture labs, animal models, information from other $\mathrm{CoV}$ species and use of a cocktail of antibodies. For quick production of antibodies, lead therapeutic candidates can be utilized for protein expression in bacteria, yeast or insect cells [49]. A much promising approach for producing neutralizing antibodies can be immunizing sheep, goat, cow or large animals with the SARS-CoV-2 proteins followed by purification of antibodies from the animals [50]. The challenge associated with the use of large animals is that there is no guarantee that they will produce neutralizing antisera or not. Another complication may be the human immune response against foreign antibodies.

\section{UTILIZING OLIGONUCLEOTIDES AGAINST SARS- COV-2}

The RNA genome of the SARS-CoV-2 could be targeted against COVID-19. RNA genome sequence (GenBank: MN908947.3) for this has been recently published and it can be targeted through small interfering RNAs or antisense oligonucleotides [51]. But the challenging task in this approach is to deliver oligonucleotides into the lungs. Another complication associated with this strategy is the non-availability of RNA sequence domains of SARS-CoV-2. Advancements in lipid nanoparticle-based drug delivery systems can deliver into the lungs but only up to a limited extent [52]. But if it becomes possible to deliver small RNAs or antisense oligonucleotides even up to $25 \%$ of epithelial cells, it may lead to great success for traditional gene therapy. The need of the hour is to discover the gene homology of SARS-CoV-2 and solve it for future drug development.

\section{UTILIZING RECOVERED PATIENT SERA}

Another promising and simple approach is the transfer of passive antibodies from the serum of a patient recovered from COVID-19 to treat a suffering patient. These polyclonal antibodies neutralize the virus and can prevent the possibility of a new infection. The cured patients can donate their plasma, which can be transfused to the suffering patient $[53,54]$. The challenging task in this approach is variability in the sera of cured and infected individuals. Although exponential prevalence of this disease may retard the scope of this therapy it still should be considered as an important strategy in the field of transfusion medicines.

\section{DEVELOPMENT OF ACE2 BINDING ANTIBODIES}

Administration of antibodies that can bind and block the action of ACE2 could be a significant approach to prevent the prevalence of COVID-19 infection. This strategy has been proved experimentally against SARS entry and replication [55]. Although no sequence of ACE2 genome is published, still monoclonal antibodies exist and hybridoma sequences can be cloned only in a few days. It is not concerned with the viral escape from the ACE2 binding antibody unlike the approaches against $\mathrm{S}$ protein [56]. The limitation of this approach is that other ACE2 receptors in different locations will also get inhibited. Also, the dose to block the ACE2 receptor in different organs of the body is not known. Another complication is turnover number of the ACE2 receptor, which will greatly influence the effect of the administered antibody. This issue can be resolved by increasing the concentration of ACE2 antagonists at the site of infection in the lungs via nebulization technique. Another unfortunate possibility is that direct binding to ACE2 may cause lung injury or may alter the physiology of the lungs.

\section{DEVELOPMENT OF ANTIBODY LIKE MOLECULE AGAINST ACE2}

Beyond developing antibodies, design and development of antibody-like therapeutic candidate against ACE2 is a much more promising approach which will directly bind and block ACE2. The validity of this approach has already been supported by literature where SARS virus was blocked from infecting cells utilizing soluble ACE2 [57]. The reported affinity of soluble ACE2 for the SARS S protein was $1.70 \mathrm{nM}$, which is comparable to the affinities of monoclonal antibodies. The life span of the circulating molecule can be increased by converting soluble ACE2 into immunoadhesin format by fusing with the immunoglobulin Fc domain (ACE2-Fc) [58]. 
Using ACE2 as SARS-CoV-2 neutralizing agent is advantageous because it can directly treat pneumonia pathophysiology. The advanced therapy suggested that the administration of recombinant ACE2 has significantly improved the acute lung injury by reducing angiotensin II levels by successive attachment of hormones to its 1a type receptor. Due to such excellent clinical abilities, recombinant ACE2 was moved to clinical trials where it revealed significant results. The limitation of ACE2-Fc therapy is that elevated extracellular levels of ACE2 in body may lead to undesirable effects. Another important outcome is that receptor targeting through an antibody can direct SARS-CoV-2 towards infecting Fc receptor-positive cells which has the capability to neutralize the antibodies. But this aspect is unclear and more clinical data is required to reveal the undiscovered mechanisms.

\section{REPURPOSING OF PREVIOUSLY APPROVED ANTI-VIRAL DRUGS}

Previously approved anti-HIV drugs can be repurposed for their efficacy against SARS-CoV-2 by focussing their inhibitory potentials against SARS-CoV-2 target proteins. Therefore drug repurposing is an attractive approach to the researchers, medicinal chemists, clinicians and drug developers in the present situation [59]. Drug repurposing is a technique for utilization of the therapeutic value of an existing drug by focusing on infections other than that for which it was initially proposed [60]. Several drugs have already been repurposed in order to develop a suitable therapeutic candidate against COVID-19. The repurposed drugs include Lopinavir, Ritonavir, Darunavir (against protease); Remdesivir, Ribavirin, Gallidesivir, Penciclovir (against RNA dependent RNA polymerase); Baloxavir (against endonuclease), chloroquine (against ACE2) and Baricitinib (against JAK kinase) [61]. Most of the repurposed drugs have cleared phase I trials (Table 1), have low risk of failure as well as a very small investment. This approach is able to facilitate great clinical developments at a very low cost. Drug repurposing sometimes may come into light through chance observations, but target based repurposing is based on a thorough understanding of molecular mechanisms or cellular events $[62,63]$. The repurposed drug may or may not work through the same target or mechanism for which it was previously approved. Many recent reports are there where researchers have carried out drug repurposing by targeting on different-different receptors or biomolecules. Hobartner et al. have carried out repurposing of antiviral drug tenofovir for orthogonal RNA catalyzed labeling of RNA [64]. Sun et al. carried out drug repurposing of pyrimidine analogs as potent antiviral compounds against human enterovirus A71 infection with potential clinical applications [65]. Bhatia et al. have reported repurposing of RdRp inhibitors against SARS-CoV-2 through molecular docking tools with promising results [60]. Zhou et al. has carried out network based repurposing of drugs against SARS-CoV-2 and screened out 16 repurposable drugs, including melatonin, quinacrine, colchicine, mercaptopurine, irbesartan etc [66]. Another work was put forward by Singh et $a l$. where they screened out a library of 123 drugs and isolated inhibitors (Raltegravir, Paritaprevir, Bictegravir and Dolutegravir) of $3 \mathrm{CL}$ pro and ribose methyltransferase through repurposing approach [67]. Kang et al. identified the SARS-
CoV-2 3C like protein inhibitory potentials of atazanavir (antiHIV drug) by utilizing Molecule Transformer-Drug Target Interaction (MT-DTI) for repurposing [68]. In another report, Yelekci et al. have utilized the drug repurposing approach by targeting 3CL hydrolases and proteases of SARS-CoV-2. They screened out talampicillin, lurasidone, rubitecan and loprazolam as potential inhibitors of these enzymes through molecular modelling tools [69]. Beyond these reports, many others are available in the literature and continuous work is in progress utilizing this drug repurposing approach.

The challenge associated with drug repurposing is the inadequate efficacy of single therapeutic candidate. Another complication associated with this approach is to search and analyze the huge amount of previously reported data to make efficient and effective use against a new indication. The complex/unclear events of the pathophysiology of SARSCoV-2 also offer a great challenge to select a candidate for repurposing.

\section{CONCLUSION}

Although there is continuous work in progress in some of the above mentioned approaches, but there is still no drug/vaccineavailable to treat COVID-19. Drug repurposing offers an economical and rapid strategy to discover a potential therapeutic agent in the current hectic situation. This compilation may be helpful to the researchers, drug developers and health agencies to look into the matter and work against the possible targets to develop a therapeutic candidate against COVID-19.

\section{CONSENT FOR PUBLICATION}

Not applicable.

\section{FUNDING}

None.

\section{CONFLICT OF INTEREST}

The author declares no conflict of interest, financial or otherwise.

\section{ACKNOWLEDGMENTS}

Declared none.

\section{REFERENCES}

[1] Cascella M, Rajnik M, Cuomo A, et al. Features, evaluation and treatment coronavirus (COVID-19). StatPearls. Treasure Island, FL: StatPearls Publishing 2020. https://www.ncbi.nlm.nih.gov/books/ NBK554776/ Updated 2020 Mar 20 Internet

[2] WHO. Coronavirus disease (COVID-19) outbreak. https://www. who.int/emergencies/diseases/novel-coronavirus-2019

[3] Saif LJ. Animal Corpnaviruses: Lessons for SARS Learning from SARS: Preparing for the Next Disease Outbreak: Workshop Summary Washington (DC). US: National Academies Press 2004. https:// www.ncbi.nlm.nih.gov/books/NBK92442/

[4] Alekseev KP, Vlasova AN, Jung K, et al. Bovine-like coronaviruses isolated from four species of captive wild ruminants are homologous to bovine coronaviruses, based on complete genomic sequences. J Virol 2008; 82(24): 12422-31.

[http://dx.doi.org/10.1128/JVI.01586-08] [PMID: 18842722]

[5] Belouzard S, Millet JK, Licitra BN, Whittaker GR. Mechanisms of coronavirus cell entry mediated by the viral spike protein. Viruses 
2012; 4(6): 1011-33.

[http://dx.doi.org/10.3390/v4061011] [PMID: 22816037]

[6] Paules CI, Marston HD, Fauci AS. Coronavirus infections-More than just the common cold. JAMA 2020; 323: 707.

[http://dx.doi.org/10.1001/jama.2020.0757] [PMID: 31971553]

[7] Mason RJ. Pathogenesis of COVID-19 from a cell biology perspective. Eur Respir J 2020; 55(4): 2000607. [http://dx.doi.org/10.1183/13993003.00607-2020] [PMID: 32269085]

[8] Wan Y, Shang J, Graham R, Baric RS, Li F. Receptor recognition by novel coronavirus from Wuhan: An analysis based on decade-long structural studies of SARS. J Virol 2020; 94(7): e00127-20. [http://dx.doi.org/10.1128/JVI.00127-20] [PMID: 31996437]

[9] Hoffmann M, Kleine-Weber H, Schroeder S, et al. SARS-CoV-2 cell entry depends on ACE2 and TMPRSS2 and is blocked by a clinically proven protease inhibitor. Cell 2020; 181(2): 271-280.e8. [http://dx.doi.org/10.1016/j.cell.2020.02.052] [PMID: 32142651]

[10] Perlman S, Netland J. Coronaviruses post-SARS: update on replication and pathogenesis. Nat Rev Microbiol 2009; 7: 439e450. [http://dx.doi.org/10.1038/nrmicro2147]

[11] Sims AC, Baric RS, Yount B, Burkett SE, Collins PL, Pickles RJ. Severe acute respiratory syndrome coronavirus infection of human ciliated airway epithelia: Role of ciliated cells in viral spread in the conducting airways of the lungs. J Virol 2005; 79(24): 15511-24. [http://dx.doi.org/10.1128/JVI.79.24.15511-15524.2005] [PMID: 16306622]

[12] Tang NL, Chan PK, Wong CK, et al. Early enhanced expression of interferon-inducible protein-10 (CXCL-10) and other chemokines predicts adverse outcome in severe acute respiratory syndrome. Clin Chem 2005; 51(12): 2333-40.

[http://dx.doi.org/10.1373/clinchem.2005.054460] [PMID: 16195357]

[13] Hancock AS, Stairiker CJ, Boesteanu AC, et al. Transcriptome analysis of infected and bystander type 2 alveolar epithelial cells during influenza A virus infection reveals in vivo Wnt pathway downregulation. J Virol 2018; 92(21): e01325-18.

[http://dx.doi.org/10.1128/JVI.01325-18] [PMID: 30111569]

[14] Qian Z, Travanty EA, Oko L, et al. Innate immune response of human alveolar type II cells infected with severe acute respiratory syndromecoronavirus. Am J Respir Cell Mol Biol 2013; 48(6): 742-8 [http://dx.doi.org/10.1165/rcmb.2012-0339OC] [PMID: 23418343]

[15] Wang J, Nikrad MP, Phang T, et al. Innate immune response to influenza A virus in differentiated human alveolar type II cells. Am J Respir Cell Mol Biol 2011; 45(3): 582-91

[http://dx.doi.org/10.1165/rcmb.2010-0108OC] [PMID: 21239608]

[16] Rockx B, Baas T, Zornetzer GA, et al. Early upregulation of acute respiratory distress syndrome-associated cytokines promotes lethal disease in an aged-mouse model of severe acute respiratory syndrome coronavirus infection. J Virol 2009; 83(14): 7062-74 [http://dx.doi.org/10.1128/JVI.00127-09] [PMID: 19420084]

[17] Wu J, Wu X, Zeng W, et al. Chest CT findings in patients with corona virus disease 2019 and its relationship with clinical features. Invest Radiol 2020. in press

[18] Kumar PA, Hu Y, Yamamoto Y, et al. Distal airway stem cells yield alveoli in vitro and during lung regeneration following H1N1 influenza infection. Cell 2011; 147(3): 525-38. [http://dx.doi.org/10.1016/j.cell.2011.10.001] [PMID: 22036562]

[19] Xu Z, Shi L, Wang Y, et al. Pathological findings of COVID-19 associated with acute respiratory distress syndrome. Lancet Respir Med 2020; 8(4): 420-2.

[http://dx.doi.org/10.1016/S2213-2600(20)30076-X] [PMID: 32085846]

[20] Prajapat M, Sarma P, Shekhar N, et al. Drug targets for corona virus: A systematic review. Indian J Pharmacol 2020; 52(1): 56-65. [http://dx.doi.org/10.4103/ijp.IJP 115 20] [PMID: 32201449]

[21] Hilgenfeld R. From SARS to MERS: Crystallographic studies on coronaviral proteases enable antiviral drug design. FEBS J 2014; 281(18): 4085-96

[http://dx.doi.org/10.1111/febs.12936] [PMID: 25039866]

[22] Wang H, Xue S, Yang H, Chen C. Recent progress in the discovery of inhibitors targeting coronavirus proteases. Virol Sin 2016; 31(1): 24-30.

[http://dx.doi.org/10.1007/s12250-015-3711-3] [PMID: 26920707]

[23] Treatment of COVID-19 patients with Anti-interleukin drugs https://clinicaltrials.gov/ct2/show/NCT04330638

[24] Richardson P, Griffin I, Tucker C, et al. Baricitinib as potential treatment for 2019-nCoV acute respiratory disease. Lancet 2020; 395(10223): e30-1.

[http://dx.doi.org/10.1016/S0140-6736(20)30304-4] [PMID:
32032529

[25] Bevacizumab in severe or critical patients with COVID-19 pneumonia (BEST-CP). https://clinicaltrials.gov/ct2/show/NCT04275414

[26] Duddu P. Coronavirus treatment: Vaccines/drugs in the pipeline for COVID-19. Clinical Trials Arena Analysis 2020.

[27] Wang M, Cao R, Zhang L, et al. Remdesivir and chloroquine effectively inhibit the recently emerged novel coronavirus (2019$\mathrm{nCoV}$ ) in vitro. Cell Res 2020; 30(3): 269-71.

[http://dx.doi.org/10.1038/s41422-020-0282-0] [PMID: 32020029]

[28] Efficacy and safety of darunavir and cobicistat for treatment of COVID-19 (DC-COVID-19). https://clinicaltrials.gov/ ct2/show/ NCT04252274

[29] Diurno F, Numis FG, Porta G, et al. Eculizumab treatment in patients with COVID-19: Preliminary results from real life ASL Napoli 2 Nord experience. Eur Rev Med Pharmacol Sci 2020; 24(7): 4040-7. [PMID: 32329881]

[30] Cai Q, Yang M, Liu D, et al. Experimental Treatment with Favipiravir for COVID-19: An Open-Label Control Study. Engineering (Beijing) 2020 .

[http://dx.doi.org/10.1016/j.eng.2020.03.007] [PMID: 32346491]

[31] Warren TK, Wells J, Panchal RG, et al. Protection against filovirus diseases by a novel broad-spectrum nucleoside analogue BCX4430. Nature 2014; 508(7496): 402-5.

[http://dx.doi.org/10.1038/nature13027] [PMID: 24590073]

[32] O'Keefe BR, Giomarelli B, Barnard DL, et al. Broad-spectrum in vitro activity and in vivo efficacy of the antiviral protein griffithsin against emerging viruses of the family Coronaviridae. J Virol 2010; 84(5): 2511-21.

[http://dx.doi.org/10.1128/JVI.02322-09] [PMID: 20032190]

[33] Sheahan TP, Sims AC, Leist SR, Schafer A, et al. Comparative therapeutic efficacy of remdesivir and combination lopinavir, ritonavir, and interferon beta against MERS-CoV Nat. Commun 2020. [http://dx.doi.org/10.1038/s41467-019-13940-6.]

[34] Zhijian X, Cheng P, Yulong S, et al. Nelfinavir was predicted to be a potential inhibitor of 2019-nCov main protease by an integrative approach combining homology modelling, molecular docking and binding free energy calculation. bioRxiv 2020 .

[http://dx.doi.org/10.1101/2020.01.27.921627]

[35] Xu J, Shi PY, Li H, Zhou J. Broad spectrum antiviral agent niclosamide and its therapeutic potential. ACS Infect Dis 2020; 6(5): 909-15.

[http://dx.doi.org/10.1021/acsinfecdis.0c00052] [PMID: 32125140]

[36] Wang Y, Zhang D, Du G, et al. Remdesivir in adults with severe COVID-19: A randomised, double-blind, placebo-controlled, multicentre trial. Lancet 2020; 395(10236): 1569-78.

[http://dx.doi.org/10.1016/S0140-6736(20)31022-9]

[PMID: 32423584

[37] Agostini ML, Andres EL, Sims AC, et al. Coronavirus susceptibility to the antiviral remdesivir (GS-5734) is mediated by the viral polymerase and the proofreading exoribonuclease. MBio 2018; 9(2)e00221-18 [http://dx.doi.org/10.1128/mBio.00221-18] [PMID: 29511076]

[38] McCreary EK, Pogue JM. Coronavirus disease 2019 treatment: A review of early and emerging options. Open Forum Infect Dis 2020; 7(4): a105.

[http://dx.doi.org/10.1093/ofid/ofaa105] [PMID: 32284951]

[39] Elfiky AA. Anti-HCV, nucleotide inhibitors, repurposing against COVID-19. Life Sci 2020; 248: 117477.

[http://dx.doi.org/10.1016/j.lfs.2020.117477] [PMID: 32119961]

[40] Vitamin C Infusion for the Treatment of Severe 2019-nCoV Infected Pneumonia https://clinicaltrials.gov/ct2/show/NCT04264533

[41] Sanders JM, Monogue ML, Jodlowski TZ, Cutrell JB. Pharmacologic treatments for coronavirus disease 2019 (COVID-19): A review. JAMA 2020.

[http://dx.doi.org/10.1001/jama.2020.6019] [PMID: 32282022]

[42] Song Y, Yao C, Yao Y, et al. XueBiJing injection versus placebo for critically ill patients with severe community-acquired pneumonia: A randomized controlled trial Crit Care Med 2019; 47(9): e735-43. [http://dx.doi.org/10.1097/CCM.0000000000003842] [PMID: 31162191]

[43] Bennardo F, Buffone C, Giudice A. New therapeutic opportunities for COVID-19 patients with Tocilizumab: Possible correlation of interleukin-6 receptor inhibitors with osteonecrosis of the jaws. Oral Oncol 2020; 106: 104659.

[http://dx.doi.org/10.1016/j.oraloncology.2020.104659] [PMID: 32209313]

[44] Tocilizumab in COVID-19 Pneumonia (TOCIVID-19). https:// clinicaltrials.gov/ct2/show/NCT04317092. 
[45] Tortorici MA, Veesler D. Structural insights into coronavirus entry. Adv Virus Res 2019; 105: 93-116.

[http://dx.doi.org/10.1016/bs.aivir.2019.08.002] [PMID: 31522710]

[46] Casadevall A, Pirofski LA. The Ebola epidemic crystallizes the potential of passive antibody therapy for infectious diseases. PLoS Pathog 2015; 11(4): e1004717.

[http://dx.doi.org/10.1371/journal.ppat.1004717] [PMID: 25905897]

[47] Shin YW, Chang KH, Hong GW, et al. Selection of vaccinia virusneutralizing antibody from a phage-display human-antibody library. J Microbiol Biotechnol 2019; 29(4): 651-7.

[http://dx.doi.org/10.4014/jmb.1812.12024] [PMID: 30856707]

[48] Keck ZY, Wang Y, Lau P, Foung SKH. Isolation of HCV neutralizing antibodies by yeast display. Methods Mol Biol 2019; 1911: 395-419. [http://dx.doi.org/10.1007/978-1-4939-8976-8_27] [PMID: 30593641]

[49] Tripathi NK, Shrivastava A. Recent developments in bioprocessing of recombinant proteins: Expression hosts and process development. Front Bioeng Biotechnol 2019; 7: 420.

[http://dx.doi.org/10.3389/fbioe.2019.00420] [PMID: 31921823]

[50] Schmidt R, Beltzig LC, Sawatsky B, et al. Generation of therapeutic antisera for emerging viral infections. NPJ Vaccines 2018; 3: 42-10. [http://dx.doi.org/10.1038/s41541-018-0082-4] [PMID: 30323953]

[51] Qureshi A, Tantray VG, Kirmani AR, Ahangar AG. A review on current status of antiviral siRNA. Rev Med Virol 2018; 28(4): e1976. [http://dx.doi.org/10.1002/rmv.1976] [PMID: 29656441]

[52] Youngren-Ortiz SR, Gandhi NS, España-Serrano L, Chougule MB. Aerosol delivery of siRNA to the lungs. Part 1: Rationale for gene delivery systems. Kona 2016; 33: 63-85. [http://dx.doi.org/10.14356/kona.2016014] [PMID: 27081214]

[53] Mire CE, Geisbert JB, Agans KN, et al. Passive immunotherapy: Assessment of convalescent serum against ebola virus makona infection in nonhuman primates. J Infect Dis 2016; 214(Suppl. 3): S367-74.

[http://dx.doi.org/10.1093/infdis/jiw333] [PMID: 27571900]

[54] Marano G, Vaglio S, Pupella S, et al. Convalescent plasma: New evidence for an old therapeutic tool? Blood Transfus 2016; 14(2): 152-7.

[PMID: 26674811]

[55] Li W, Moore MJ, Vasilieva N, et al. Angiotensin-converting enzyme 2 is a functional receptor for the SARS coronavirus. Nature 2003; 426(6965): 450-4.

[http://dx.doi.org/10.1038/nature02145] [PMID: 14647384]

[56] Kruse RT. Therapeutic strategies in an outbreak scenario to treat the novel coronavirus originating in Wuhan, China version 2; peer review: 2 approved. F1000Research 2020; 9: 72.

[57] Zhang H, Penninger JM, Li Y, Zhong N, Slutsky AS. Angiotensinconverting enzyme 2 (ACE2) as a SARS-CoV-2 receptor: Molecular mechanisms and potential therapeutic target. Intensive Care Med 2020; 46(4): 586-90.

[http://dx.doi.org/10.1007/s00134-020-05985-9] [PMID: 32125455]

[58] Sui J, Li W, Murakami A, et al. Potent neutralization of severe acute respiratory syndrome (SARS) coronavirus by a human mAb to $\mathrm{S} 1$ protein that blocks receptor association. Proc Natl Acad Sci USA
2004; 101(8): 2536-41.

[http://dx.doi.org/10.1073/pnas.0307140101] [PMID: 14983044]

[59] Dyall J, Coleman CM, Hart BJ, et al. Repurposing of clinically developed drugs for treatment of Middle East respiratory syndrome coronavirus infection. Antimicrob Agents Chemother 2014; 58(8): 4885-93.

[http://dx.doi.org/10.1128/AAC.03036-14] [PMID: 24841273]

[60] Bhatia R, Narang RK, Rawal RK. Repurposing of RdRp Inhibitors against SARS-CoV-2 through Molecular Docking Tools. Coronaviruses 2020; $1: 1-9$

[http://dx.doi.org/10.2174/2666796701999200617155629]

[61] Liu C, Zhou Q, Li Y, et al. Research and development on therapeutic agents and vaccines for COVID-19 and related human coronavirus diseases. ACS Cent Sci 2020; 6(3): 315-31.

[http://dx.doi.org/10.1021/acscentsci.0c00272] [PMID: 32226821]

[62] Pizzorno A, Padey B, Terrier O, Rosa-Calatrava M. Drug repurposing approaches for the treatment of influenza viral infection: Reviving old drugs to fight against a long-lived enemy. Front Immunol 2019; 10: 531.

[http://dx.doi.org/10.3389/fimmu.2019.00531] [PMID: 30941148]

[63] Ashburn TT, Thor KB. Drug repositioning: identifying and developing new uses for existing drugs. Nat Rev Drug Discov 2004; 3(8): 673-83. [http://dx.doi.org/10.1038/nrd1468] [PMID: 15286734]

[64] Maghami MG, Dey S, et al. Repurposing antiviral drugs for orthogonal RNA catalyzed labeling of RNA. Angewandtey chemie 2020.

[65] Sun J, Yogarajah T, Lee RCH, et al. Drug repurposing of pyrimidine analogs as potent antiviral compounds against human enterovirus A71 infection with potential clinical applications. Sci Rep 2020; 10(1): 8159 .

[http://dx.doi.org/10.1038/s41598-020-65152-4] [PMID: 32424333]

[66] Zhou Y, Hou Y, Shen J, Huang Y, Martin W, Cheng F. Network-based drug repurposing for novel coronavirus 2019-nCoV/SARS-CoV-2. Cell Discov 2020; 6: 14 .

[http://dx.doi.org/10.1038/s41421-020-0153-3] [PMID: 32194980]

[67] Khan RJ, Kumar JR, et al. Targeting novel coronavirus 2019: A systematic drug repurposing approach to identify promising inhibitors against 3C-like proteinase and 2'-O-ribose methyl- transferase. ChemRxiv 2020.

[http://dx.doi.org/10.26434/chemrxiv.11888730.v1]

[68] Beck BR, Shin B, Choi Y, Park S, Kang K. Predicting commercially available antiviral drugs that may act on the novel coronavirus (SARS$\mathrm{CoV}-2$ ) through a drug-target interaction deep learning model. Comput Struct Biotechnol J 2020; 18: 784-90.

[http://dx.doi.org/10.1016/j.csbj.2020.03.025] [PMID: 32280433]

[69] Elmezayen AD, Al-Obaidi A, Şahin AT, Yelekçi K. Drug repurposing for coronavirus (COVID-19): In silico screening of known drugs against coronavirus $3 \mathrm{CL}$ hydrolase and protease enzymes. J Biomol Struct Dyn 2020; 1-13.

[http://dx.doi.org/10.1080/07391102.2020.1758791] [PMID: 32306862] 